\title{
Consumer Preference towards Choosing EBO vs. MBO with Special Reference to Apparel Retailing
}

\author{
Ritika Valecha', Dr. Fezeena Khadir ${ }^{2}$ \\ ${ }^{1}$ BBA H alumnus, Class of 2020, Christ Deemed To Be University, Bangalore Bannerghatta Road Campus, Bannerghatta Road, \\ Hulimavu, Bengaluru \\ ${ }^{2}$ Asst. Professor, Christ Deemed To Be University, Bangalore Bannerghatta Road Campus, Bannerghatta Road, Hulimavu, \\ Bengaluru
}

\begin{abstract}
This article has been written with a primary question: 'With so many choices available in the apparel industry, what drives customers to a particular branded store?' Although there are various reasons, the store format remains to be an important one, according to extant literature. When brands select their distribution channels, they face the dilemma of choosing a retail format. The study aims to find out which store format (Exclusive brand store or Multi-brand store) is preferable by the consumers and the factors affecting this choice. A survey of 155 people from Bangalore, who have access to branded stores, was conducted and various tests were performed. The results showed that most of the consumers prefer MBO over EBO. The 12 factors identified were reduced into two groups using factor analysis, out of which the attributes relating to the store have more impact on the consumer's decision than attributes relating to the merchandise.
\end{abstract}

KEYWORDS: Apparel, Consumer Preference, Exclusive Brand Store, Multi Brand Store, Retail Store Format

\section{INTRODUCTION}

Since globalization, the retail markets are constantly growing and brands have found a significant position in minds of the consumer, thus their choices and purchasing decision revolves around these brands. Due to the upcoming of various store formats today, the entire clothing industry has seen a major shift (Kumar, 2015). This creates the dilemma for both, retailers and consumers, to choose a retail format while apparel shopping.

For the purpose the study, two retail store formats have been considered namely, exclusive brand stores (EBO) and multi-brand stores (MBO). Exclusive brand store refers to the format where the store is dedicated to one brand and exclusively shelves the products from the brand. For example, various companies like, Adidas, Zara, H\&M, Levis, IKEA etc, have set up exclusive brand stores. Multi-brand store refers to the retail stores that are not dedicated to one particular brand but keep various brands from the same category. Some of the famous multi brand stores include shopper's stop. It keeps stalks of various brands like W, Puma, Veromoda and other such brands. Other examples include Reliance, Big Bazaar, and Central etc.

Every retailer seeks to get more and more customers and retain them for a long time by improving their shopping experience which is highly affected by the store layout and design (Kotni, 2016). Although consumers visit both store formats, they tend to prefer one type of store format over the other. This choice is usually not made by the consumers consciously but the consumer unconsciously or sub-consciously prefers one format over the other due to various factors. In the current competitive scenario, it is essential for retailers to understand the behavior of the consumers which can be done by understanding the importance of such factors in order to enhance their shopping experience.

Some of these factors include variety of products, convenience, product quality, price and store loyalty (Zulqarnain et. al., 2015). The factors also include location convenience, store accessibility and availability of public transport, multi store locations and store visibility from traffic point, which signifies considering a good store location is very crucial for any organized retail store (Behra and Mishra, 2017).

Further, the consumers do not prefer a complex layout even though it seems fascinating for once but when they actually have to make purchases they prefer simple designs. The negative effect that is seen in the stores with high visual complexity reduces when the design is made simpler. Therefore, there is a negative relationship between the visual complexity of store and consumer response towards the store. This means that retailers must try to use the limited store space available to them in an effective way and assort 


\section{International Journal of Current Science Research and Review}

ISSN: 2581-8341

Volume 04 Issue 06 June 2021

DOI: 10.47191/ijcsrr/V4-i6-08, Impact Factor: 5.825

IJCSRR@ 2021

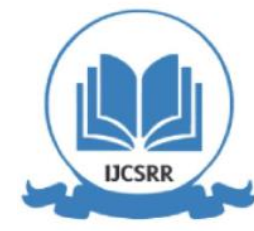

www.ijcsrr.org

the products with least complexity to increase consumer attention and ease in shopping that ultimately leads to increase in sales (Jang et. al., 2018). The design of the store and ease of shopping is associated with customer satisfaction which in turn is connected to customer retention. Further, if these attributes have a positive relationship with the time customers spend in the store (Turhan, 2014).

Various factors of store ambience including lighting, music, color and visual merchandising also display a positive relationship with consumer experience which in turn has a positive impact on consumer buying behavior (Channer et. al., 2015). The visual merchandising aspects differ in men and women. Women are more attracted towards the mannequin display and promotional signage whereas men have higher tendency towards the layout of the store. In-store product display does not have an effect as significant as other aspects of visual merchandising. Therefore, proper usage of visual merchandising can not only attract the target customers but also would make them spend more time in the store. This in turn will lead to increase in impulse buying, thus an increase in the overall sales of the store (Dash and L., 2016).

Other factors involved are related to parking facilities like characteristics of the store, the distance between the store and the parking lot, number of parking spaces available, the price of parking the vehicles, location of parking and facility of trolleys at the parking lot. Various models of the shopping centers along with the parking lots have different effects on the choices and preferences of the consumers. Consumers' choice is highly affected by the distance between the shopping center and the parking lot. Further, customer chooses a parking lot more often if the size of that parking lot is smaller, indicating that they do not have to walk more in order to reach the shopping center and back to parking lot (Waerden et. al., 1998).

Consumer's attitude towards retail promotions is another considerable variable and designing promotion strategies increase footfalls in the store and the sales generated. There are three types of price perceptions present namely, discounts, promotional offers and loyalty cards. The attitude and the behavior of the consumers towards these price cuts or promotions highly depend on a few factors. Three major factors among the group of all factors namely, shopping factors, price consciousness and deal or coupon proneness (Khare et. al., 2013). Such factors help retailers to get more customers to their stores but retaining such customers is another key aspect. Consumer loyalty is linked to customer satisfaction and store image. Satisfaction increases the chances of any consumer to recommend the store to other consumers which would increase the footfall in the store and additionally would make the original customer more loyal. Further, there is no direct link between the store image and customer loyalty but store image has a positive relationship with consumer satisfaction as it gives consumers a sense of pride when they shop form a reputed store. This increase in consumer satisfaction leads to increase in consumer loyalty and thus shows an indirect impact. This way both, consumer satisfaction and store image are linked to customer loyalty (Thomas, 2013). Therefore, customer satisfaction and store image are considered to be important factors while choosing a store.

The above mentioned factors affect the choice of the store but the intensity of influence on the customers varies in different store formats. Some of them drive consumers towards exclusive brand stores and others to multi brand stores. Multi brand stores are majorly affected by store image followed by wider choice and offers and promotions (Kumar, 2015). Other set of factors drive customers to select an EBO. These kinds of shops in India are perceived as up market, expensive, fashionable and young. The consumer segment is young and looking for trendy products more for good looks and aesthetics rather than actual functional usage (Kureshi et. al., 2015).

Looking at the current trends in the market, the distribution channel of retailers is fast moving towards the e-tailing but it is not possible for the retailers to completely shift towards the online channel. No brand can afford at least at this moment to lose their more than 50\% contributor which is scattered channel (Khare, 2017) indicating that offline distribution of the goods is necessary, especially in a country like India. This creates a need to pay special attention towards the physical attributes of the store.

The purpose of this paper is to determine whether or not, the retail format of a store plays an important role in the apparel purchasing decisions, identify the more preferred retail format between exclusive brand store and multi brand store by the consumers and find out various factors that drive consumers to choose between different retail formats. For any company, it is important to understand what its customers prefer in terms of the retail formats and what drive them to a particular store. This would help them to determine their distribution channel and the store and merchandise attributes required to cover in order to capture a broader market.

\section{OBJECTIVES OF THE STUDY}

1. To determine whether or not, the retail format of a store plays an important role in the apparel purchasing decisions. 


\section{International Journal of Current Science Research and Review}

ISSN: 2581-8341

Volume 04 Issue 06 June 2021

DOI: 10.47191/ijcsrr/V4-i6-08, Impact Factor: 5.825

2. To identify the more preferred retail format between exclusive brand store and multi brand store by the consumers.

3. To find out various factors that drive consumers to choose between different retail formats.

\section{STATEMENTS OF HYPOTHESES}

H1: Males and females differ in the frequency of visit to EBO.

$\mathrm{H} 2$ : Males and females differ in the frequency of visit to MBO.

H3: Consumers with different income groups differ in the frequency of visit to EBO.

H4: Consumers with different income groups differ in the frequency of visit to MBO.

H5: There is a significant relationship between frequency of visit to EBO and $\mathrm{MBO}$ and amount spent in EBO and MBO per visit.

H6: Consumers with different income groups differ in the amount spent in EBO.

H7: Consumers with different income groups differ in the amount spent in MBO

H8: There is a significant difference in Consumer Choice of Retail Format due to Factors

\section{METHODOLOGY}

The research conducted is a descriptive study as it will be used to describe what is more preferred retail format by the consumer and the reasons for the same. It gives answer to "what" consumers prefer. Here, we try to understand the frequency of visit by the consumer and related statistical data. The study also tries to describe the related data through the literature and research conducted previously, post which further data is collected.

The literature helped to identify 12 factors for consideration. The twelve factors take here are friendliness of sales personnel, personalized services, display of merchandise, store design, store ambience, parking facilities, customer loyalty programs, convenient store location, availability of quality merchandise, availability of wide choice of the merchandise, value of money for merchandise and frequency of promotional offers. In regards to the study, a consumer based questionnaire was prepared and distributed amongst individuals who are selected as the sample in order to collect primary data for the study. The questionnaire was structured in the form of close ended questions. It consisted of two sections. The first section consisted questions regarding the demographic profile of the consumers whereas the second section consisted of questions regarding the apparel purchase. Data collected was reviewed and 155 responses were taken in consideration for the study.

Data processing of this study has been done using SPSS by IBM, version 21. The software was used in this study to run statistical tests like, reliability test, t-test, ANOVA, correlation, factor analysis to arrive at the results.

\section{DATA ANALYSIS AND INTERPRETATION}

The summarized analysis of the data is given below:

Frequency of Purchase

Chart 1: Distribution of Frequency of Purchase

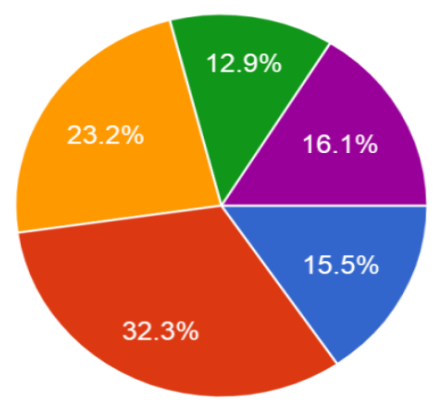

Less than 3 times

3- 6 times

6 - 9 times

9 - 12 times

More than 12 times 


\section{International Journal of Current Science Research and Review}

ISSN: 2581-8341

Volume 04 Issue 06 June 2021

DOI: 10.47191/ijcsrr/V4-i6-08, Impact Factor: 5.825

IJCSRR@ 2021

www.ijjcsrr.org

The above graph represents the number of times customers visit an apparel store in a year.It was found that $32.3 \%$ of the respondents shop for 3-6 times in a year, which is chosen by most of the respondents. This was followed by the respondents who visit the store 6-9 times

in a year with a percentage of $23.2 \%$. Further, it was followed by other 3 categories.

Frequency of Visit to the Store Formats

Chart 2: Distribution of Frequency of Visit to $\mathrm{EBO}$ and $\mathrm{MBO}$

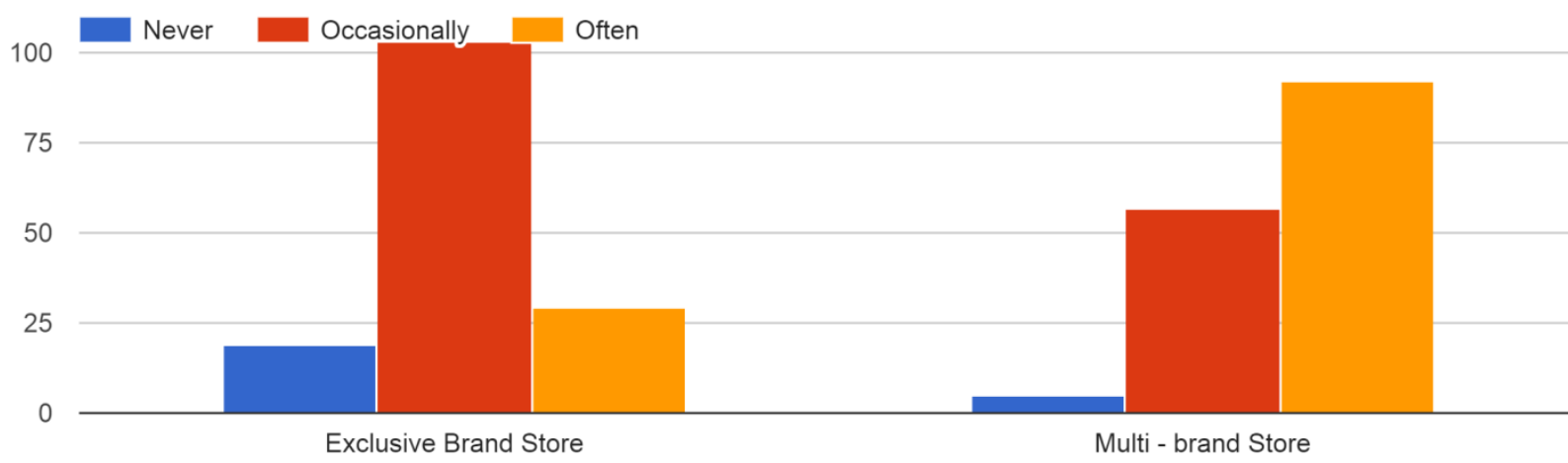

Table 1. Frequency of Visit to EBO

\begin{tabular}{|l|c|c|}
\hline & Frequency & Percent \\
\hline Never & 18 & 11.6 \\
\hline Occasionally & 107 & 69.0 \\
\hline Often & 30 & 19.4 \\
\hline Total & $\mathbf{1 5 5}$ & $\mathbf{1 0 0 . 0}$ \\
\hline
\end{tabular}

The above table clearly shows that most of the people visit to exclusive brand stores on an occasional basis. $69 \%$ of the respondents who form a majority said that they visit the store on occasional basis followed by $19.4 \%$ of the people who often visit the store whereas only 18 people do not visit an exclusive brand store at all.

Table 2. Frequency of Visit to MBO

\begin{tabular}{|l|c|c|}
\hline & Frequency & Percent \\
\hline Never & 5 & 3.2 \\
\hline Occasionally & 57 & 36.8 \\
\hline Often & 93 & 60.0 \\
\hline Total & $\mathbf{1 5 5}$ & $\mathbf{1 0 0 . 0}$ \\
\hline
\end{tabular}




\section{International Journal of Current Science Research and Review}

ISSN: 2581-8341

Volume 04 Issue 06 June 2021

DOI: 10.47191/ijcsrr/V4-i6-08, Impact Factor: 5.825

IJCSRR@ 2021

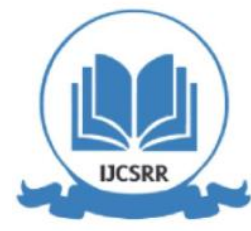

www.ijcsrr.org

The above table shows the frequency of visit to multi-brand stores by the respondents. It was found that most of the respondents often visit the multi-brand stores whereas there are only 5 respondents who never visit the store. This indicates that if not very often, the respondents visit the multi brand store on occasional basis.

Table 3. Frequency of Visit to EBO vs MBO

\begin{tabular}{|l|c|c|c|c|c|}
\hline & N & Sum & Mean & Std. Deviation & Variance \\
\hline Frequency of visit to EBO & 155 & 322.00 & 2.0774 & .55286 & .306 \\
\hline Frequency of visit to MBO & 155 & 398.00 & 2.5677 & .55852 & .312 \\
\hline
\end{tabular}

The above table shows the comparison between the frequency of visit to exclusive brand stores and frequency of visit to multi brand stores. The responses of 155 people were recorded for both questions. It can be seen that the sum as well as the mean for frequency of visit to multi brand stores is higher than frequency of visit to exclusive brand stores. This clearly shows that most of the consumers prefer visiting a multi brand store over an exclusive brand for their apparel shopping.

EBO vs. MBO

Chart 3: Consumer Choice in $\mathrm{EBO}$ and $\mathrm{MBO}$

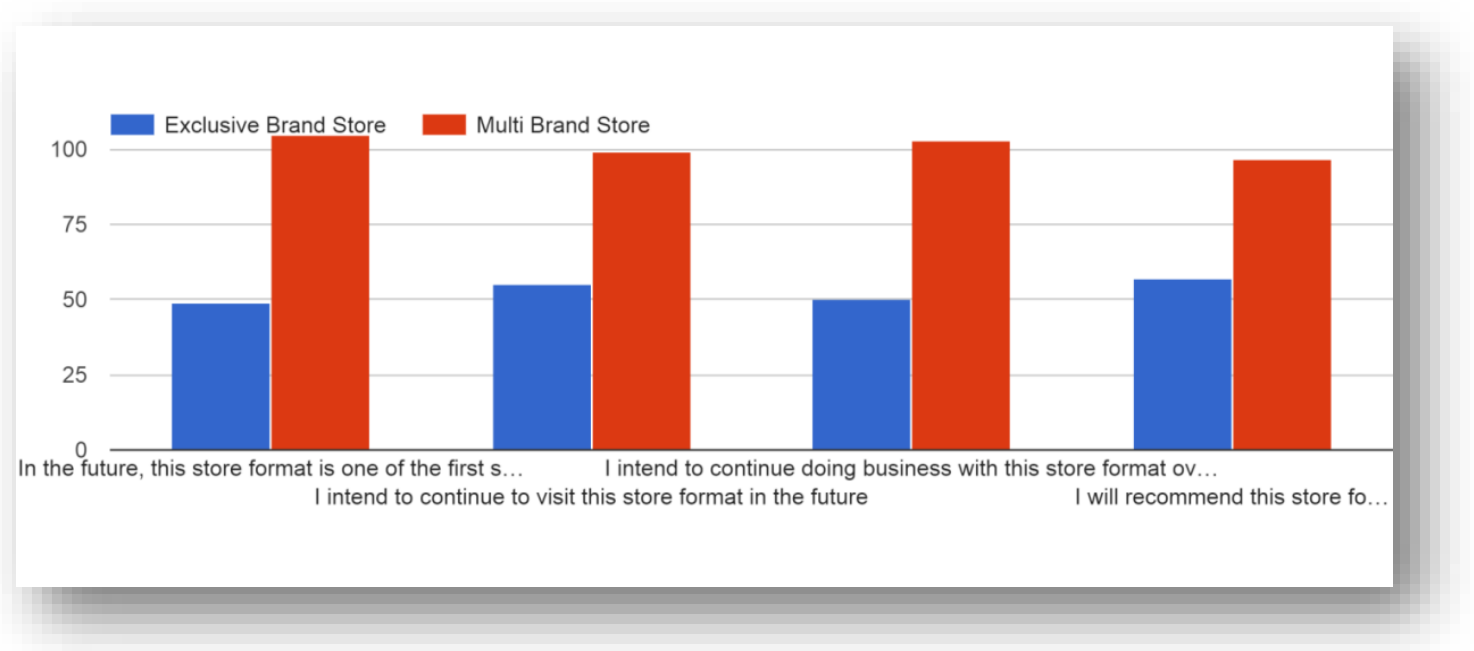

The above graph is a representation of choice made of consumers in the given situations. This was done to know the more preferred format by the respondents.

In all four situations, it is clearly evident that consumers prefer multi-brand store over exclusive brand store. The questions asked the consumers to choose a format which will be their current first preference, their future visits, their recommendations to their friends/family etc. Although, the questions were similar and tries to find the answer to same objective, it was asked in four different ways to be sure that the respondents actually answer the questions and do not randomly choose an option. Through this question, it was very clear that consumers prefer to visit the multi-brand brands than exclusive brand stores.

Relationship between Gender and Frequency of Visit to EBO and MBO

HO: Males and females do not differ in the frequency of visit to EBO.

$\mathrm{H} 1$ : Males and females differ in the frequency of visit to EBO. 
ISSN: 2581-8341

Volume 04 Issue 06 June 2021

DOI: 10.47191/ijcsrr/V4-i6-08, Impact Factor: 5.825

The results after conducting the test are as follows:

Table 4. Frequency of Visit to EBO and Gender (Statistics)

\begin{tabular}{|l|c|c|c|c|c|}
\hline & Gender & $\mathbf{N}$ & Mean & Std. Deviation & Std. Error Mean \\
\hline \multirow{2}{*}{$\begin{array}{l}\text { Frequency of Visit } \\
\text { to EBO }\end{array}$} & Male & 65 & 2.1077 & .58957 & .07313 \\
\cline { 2 - 6 } & Female & 90 & 2.0556 & .52705 & .05556 \\
\hline
\end{tabular}

The above tables gives the group statistics which shows the responses of 55 male and 90 female respondents have been considered. The means for the two groups do not have much difference.

Table 5. Frequency of Visit to EBO and Gender (Independent Samples Test)

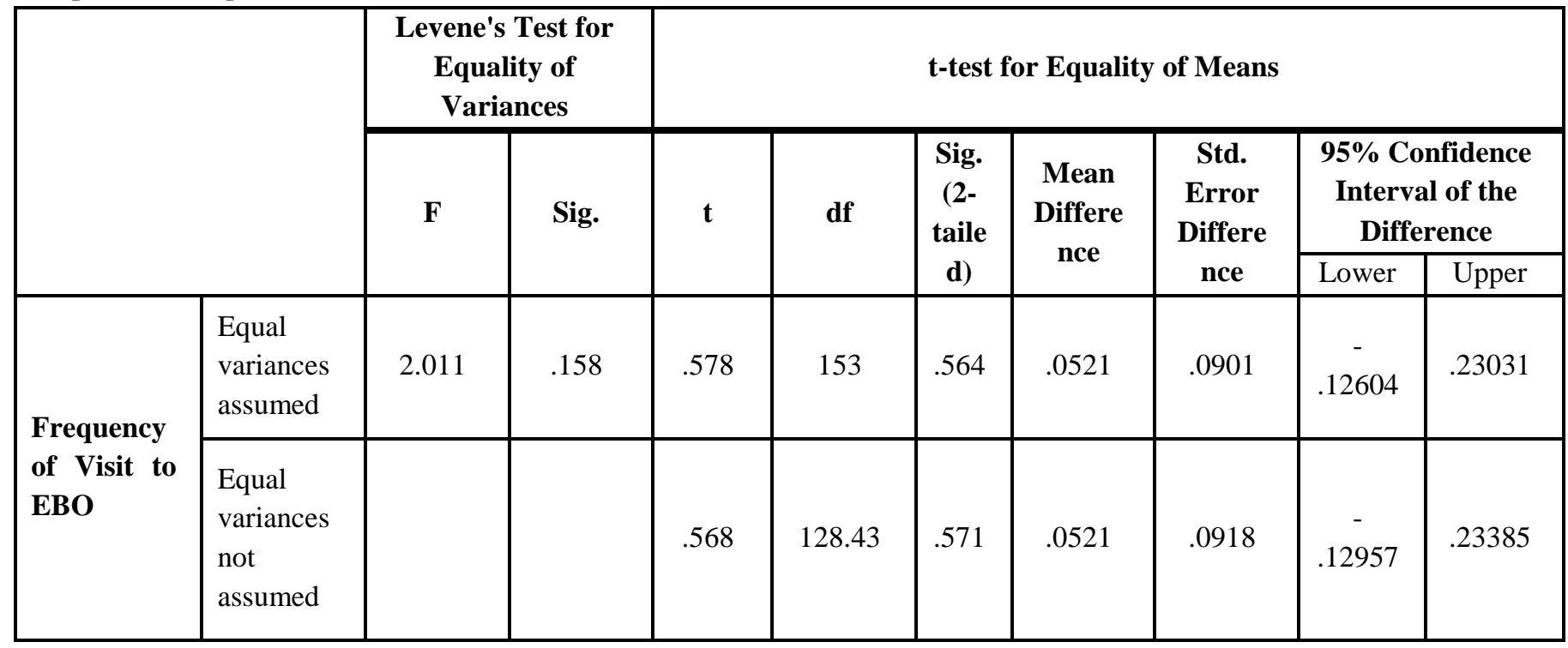

The above table shows the test result which shows that the significance value is more than 0.05 . Therefore, in this case we reject the alternate hypothesis which means there is no significant difference between male and female respondents regarding the frequency of their visit to an exclusive brand store.

H0: Males and females do not differ in the frequency of visit to MBO.

$\mathrm{H} 1$ : Males and females differ in the frequency of visit to MBO.

The results after conducting the test are as follows:

Table 6. Frequency of Visit to MBO and Gender (Statistics)

\begin{tabular}{|l|c|c|c|c|c|}
\hline & Gender & N & Mean & Std. Deviation & Std. Error Mean \\
\hline $\begin{array}{l}\text { Frequency of Visit } \\
\text { to MBO }\end{array}$ & Male & 65 & 2.4462 & .55988 & .06944 \\
\cline { 2 - 6 } & Female & 90 & 2.6556 & .54383 & .05733 \\
\hline
\end{tabular}




\section{International Journal of Current Science Research and Review}

ISSN: 2581-8341

Volume 04 Issue 06 June 2021

DOI: 10.47191/ijcsrr/V4-i6-08, Impact Factor: 5.825

IJCSRR @ 2021

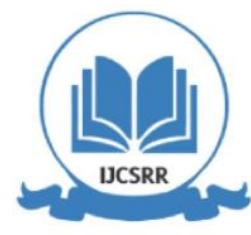

www.ijjcsrr.org

The above tables gives the group statistics which shows the responses of 55 male and 90 female respondents have been considered. The means for the two groups show that the frequency of visit to a multi-brand store is higher by females than that of males.

Table 7. Frequency of Visit to MBO and Gender

(Independent Samples Test)

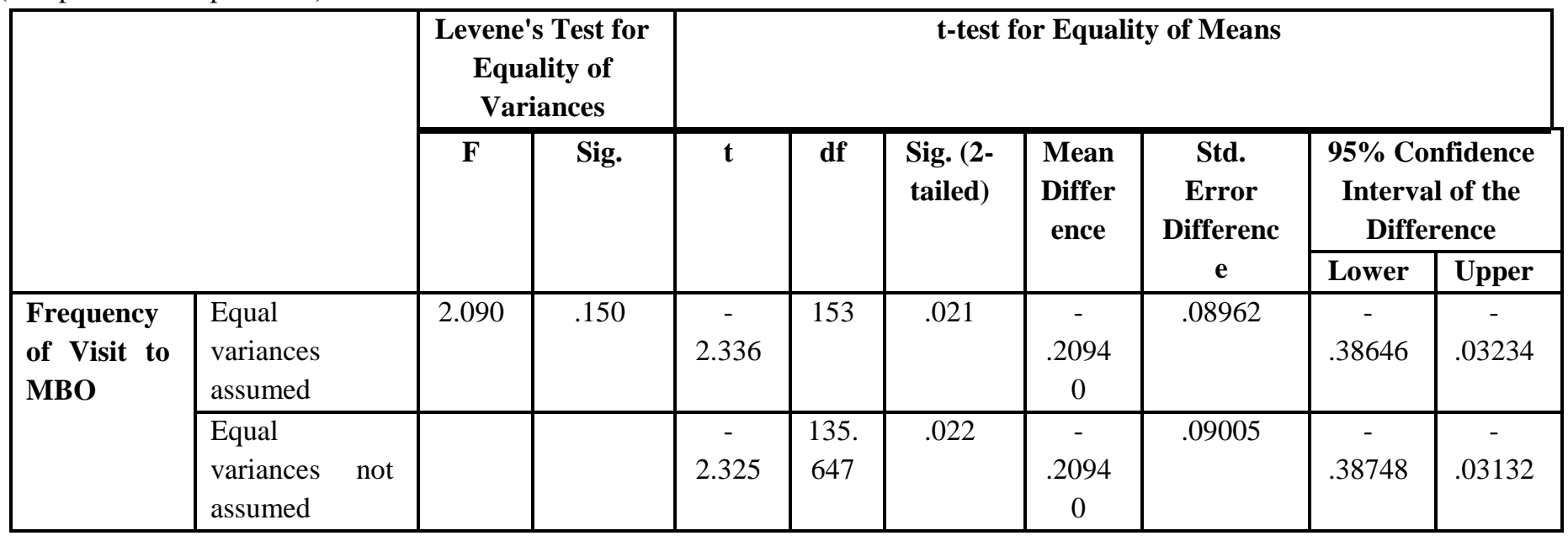

The above table shows the test result which shows that the significance value is less than 0.05 . Therefore, in this case we reject the null hypothesis and accept the alternate hypothesis which means there is a significant difference between male and female respondents regarding the frequency of their visit to a multi-brand store. Here, $\mathrm{t}(153)=-2.325$, which means that the frequency of visit to $\mathrm{MBO}$ is higher by females than males.

From the above test, it can be clearly concluded that the gender of a consumer affects the frequency of visiting a multi-brand store but not an exclusive brand store. This means the gender of a person is indifferent in terms of visiting the exclusive brand store. It is also concluded the frequency of visit to MBO is higher by females than males.

\section{Relationship between Income and Frequency of Visit to EBO and MBO}

H0: Consumers with different income groups do not differ in the frequency of visit to EBO.

H1: Consumers with different income groups differ in the frequency of visit to EBO.

The results after conducting the test are as follows:

Table 8. Frequency of Visit to EBO and Income (Anova)

\begin{tabular}{|l|l|l|l|l|l|}
\hline & Sum of Squares & df & Mean Square & F & Sig. \\
\cline { 1 - 4 } Between Groups & 2.642 & 3 & .881 & \multirow{2}{*}{2.993} & \multirow{2}{*}{.033} \\
\cline { 1 - 4 } Within Groups & 44.429 & 151 & .294 & & \\
\cline { 1 - 4 } Total & $\mathbf{4 7 . 0 7 1}$ & $\mathbf{1 5 4}$ & & & \\
\hline
\end{tabular}

The above table shows a significance value of 0.033 which is less than 0.05 . Thus, we accept the alternate hypothesis and reject the null hypothesis. This means that there is a significant difference in the frequency of visit to EBO among the income groups.

H0: Consumers with different income groups do not differ in the frequency of visit to MBO.

H1: Consumers with different income groups differ in the frequency of visit to MBO. 


\section{International Journal of Current Science Research and Review}

ISSN: 2581-8341

Volume 04 Issue 06 June 2021

DOI: 10.47191/ijcsrr/V4-i6-08, Impact Factor: 5.825

IJCSRR @ 2021

www.ijjcsrr.org

The results after conducting the test are as follows:

Table 9. Frequency of Visit to MBO and Income (Anova)

\begin{tabular}{|l|c|c|c|c|c|}
\hline & Sum of Squares & df & Mean Square & F & Sig. \\
\cline { 1 - 5 } Between Groups & .925 & 3 & .308 & .989 & .400 \\
\cline { 1 - 4 } Within Groups & 47.113 & 151 & .312 & & \\
\hline Total & $\mathbf{4 8 . 0 3 9}$ & $\mathbf{1 5 4}$ & & & \\
\hline
\end{tabular}

The above table shows the test result which shows that the significance value is more than 0.05 . Therefore, in this case we reject the alternate hypothesis which means there is no significant difference in the frequency of visit to multi-brand store among the income groups.

From the above test, it can be clearly concluded that the income level of a consumer affects the frequency of visiting an exclusive brand store but not a multi-brand store.

\section{Amount Spent at the Store Formats}

Chart 4. Distribution of Amount Spent at $\mathrm{EBO}$ and $\mathrm{MBO}$

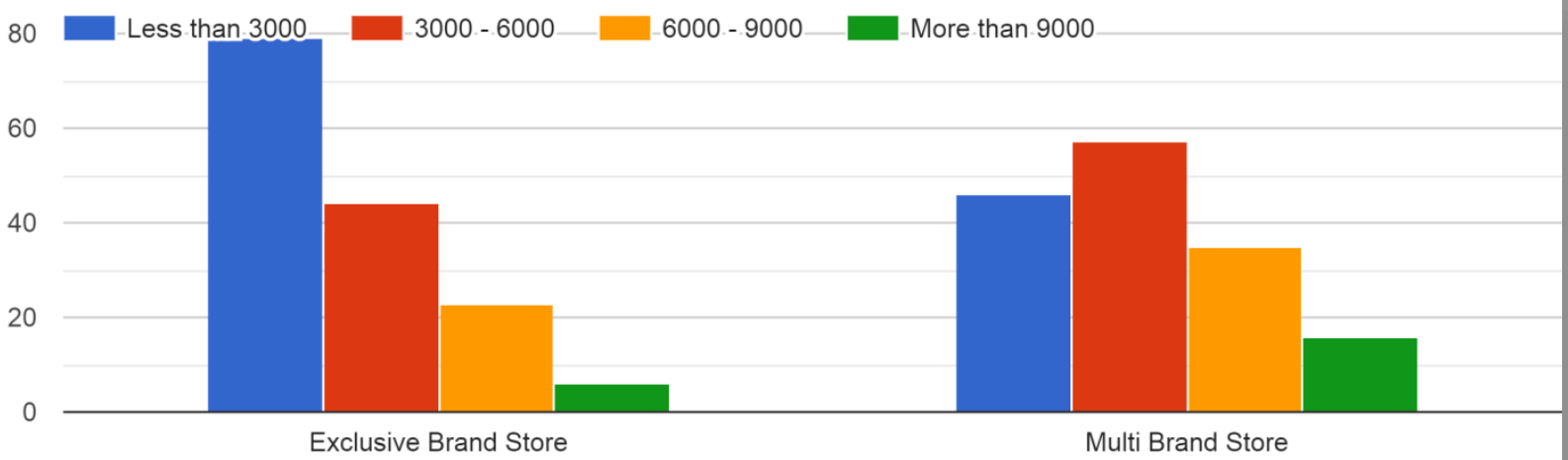

The above graph shows the amount of money spent by the consumers at each format and helped us to know at which format consumers tend to spend more.

Looking at the bar of exclusive brand store, it was found that most of the respondents spend less than 3000 at an exclusive brand store followed by the category of 3000 - 6000 and further by $6000-9000$ and more than 9000 . A clear declining slope is visible in the graph indicating that people do not prefer spending more at the exclusive brand stores. The graph of the multi-brand store shows that most of the people spend around 3000 - 6000 per visit to a multi-brand store. This is followed by the category of people who spend less than 3000 per visit. Further, a few people spend around 6000 - 9000 per visit and least number of people spend more than 9000 . This shows people spend a moderate amount of money at multi-brand stores.

Comparing the amount of money spent by consumers per visit in both the store format, it is clearly evident that they tend to spend more money at multi-brand stores than at exclusive brand stores. The reason for this can be that consumers get wide variety and 


\section{International Journal of Current Science Research and Review}

ISSN: 2581-8341

Volume 04 Issue 06 June 2021

DOI: 10.47191/ijcsrr/V4-i6-08, Impact Factor: 5.825

IJCSRR @ 2021

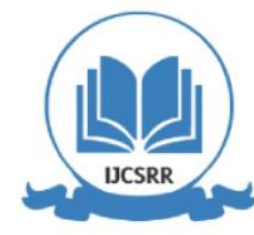

www.ijjcsrr.org

choice at multi-brand stores and want to own products from different brands instead of getting it from one particular brand. Thus, they end up spending more at the multi-brand stores.

Correlation between 'Frequency of Visit to EBO and MBO' and 'Amount Spent in EBO and MBO per visit'

H0: There is no relationship between frequency of visit to $\mathrm{EBO}$ and $\mathrm{MBO}$ and amount spent in $\mathrm{EBO}$ and $\mathrm{MBO}$ per visit

H1: There is a significant relationship between frequency of visit to $\mathrm{EBO}$ and $\mathrm{MBO}$ and amount spent in $\mathrm{EBO}$ and $\mathrm{MBO}$ per visit.

The test results are as follows:

Table 10. Frequency of Visit and Amount Spent (Correlation)

\begin{tabular}{|c|c|c|}
\hline \multicolumn{2}{|c|}{} & Amt \\
\hline \multirow{3}{*}{ Frequency } & Pearson Correlation & .284 \\
\cline { 2 - 3 } & Sig. (2-tailed) & .000 \\
\cline { 2 - 3 } & $\mathrm{N}$ & 155 \\
\hline
\end{tabular}

The above table shows the correlation between frequency of visit to MBO and EBO and amount spent in EBO and MBO. The significance value is 0.000 which is less than 0.05 which indicates that the correlation is significant. Here, the Pearson correlation value is 0.284 which indicates a positive but weak correlation between the two variables. This shows that when the frequency of visit to $\mathrm{EBO}$ and $\mathrm{MBO}$ increases, the amount spent by the consumers also increase which means they become loyal towards the store.

Relationship between Income and Amount Spent in EBO and MBO per visit

H0: Consumers with different income groups do not differ in the amount spent in EBO.

H1: Consumers with different income groups differ in the amount spent in EBO.

The results after conducting the test are as follows:

Table 11. Amount Spent in EBO and Income (Anova)

\begin{tabular}{|l|c|c|c|c|c|}
\hline & Sum of Squares & df & Mean Square & F & Sig. \\
\cline { 1 - 4 } Between Groups & 16.189 & 3 & 5.396 & \multirow{2}{*}{8.077} & .000 \\
\cline { 1 - 3 } Within Groups & 100.882 & 151 & .668 & & \\
\hline Total & $\mathbf{1 1 7 . 0 7 1}$ & $\mathbf{1 5 4}$ & & & \\
\hline
\end{tabular}

The above table shows a significance value of 0.000 which is less than 0.05 . Thus, we accept the alternate hypothesis and reject the null hypothesis. This means that there is a significant difference in the amount of money spent in EBO per visit among the various income groups.

H0: Consumers with different income groups do not differ in the amount spent in MBO

$\mathrm{H1}$ : Consumers with different income groups differ in the amount spent in MBO

The results after conducting the test are as follows: 


\section{International Journal of Current Science Research and Review}

ISSN: 2581-8341

Volume 04 Issue 06 June 2021

DOI: 10.47191/ijesrr/V4-i6-08, Impact Factor: 5.825

IJCSRR @ 2021

www.ijcsrr.org

Table 12. Amount Spent in MBO and Income (Anova)

\begin{tabular}{|l|c|c|c|c|c|}
\hline INCOME & Sum of Squares & df & Mean Square & F & Sig. \\
\hline Between Groups & 9.949 & 3 & 3.316 & 3.691 & .013 \\
\hline Within Groups & 135.690 & 151 & .899 & & \\
\hline Total & $\mathbf{1 4 5 . 6 3 9}$ & $\mathbf{1 5 4}$ & & & \\
\hline
\end{tabular}

The above table shows a significance value of 0.013 which is less than 0.05 . Thus, we accept the alternate hypothesis and reject the null hypothesis. This means that there is a significant difference in the amount of money spent in MBO per visit among the various income groups.

From the above test, it can be clearly concluded that there is a significant difference in the amount of money spent by consumers in exclusive brand stores and multi-brand stores per visit among the income groups.

\section{Relationship between the 'Factors' and 'Consumer Choice in EBO and MBO'}

For the purpose of finding if the twelve factors considered for the study have any effect on the choice of consumers in choosing one store format over the other, ANOVA was conducted. The twelve factors were combined using spss and one factor was made and used for the study.

H0: There is no significant difference in the Consumer Choice of Retail Format due to Factors

H1: There is a significant difference in Consumer Choice of Retail Format due to Factors

The results after conducting the test are as follows:

Table 13. Preference of Format and Factors (Anova)

\begin{tabular}{|l|c|c|c|c|c|}
\hline & Sum of Squares & df & Mean Square & F & Sig. \\
\cline { 1 - 5 } Between Groups & 11.155 & 40 & .279 & 1.422 & .043 \\
\hline Within Groups & 22.355 & 114 & .196 & & \\
\hline Total & $\mathbf{3 3 . 5 1 0}$ & $\mathbf{1 5 4}$ & & & \\
\hline
\end{tabular}

The above table shows a significance value of 0.043 which is less than 0.05 . Thus, we accept the alternate hypothesis and reject the null hypothesis. This means that there is a significant difference in consumer choice of retail format due to grouped factors.

Factors affecting the choice of the consumers

For the purpose of the study, there were 12 factors considered that affect the choice of the consumers while choosing an exclusive brand store or a multi brand store. These factors were found out from the previous studies conducted by various researchers in relevant field. The factors that are considered are convenient store location, availability of good quality merchandise, availability of wider choice / selection of merchandise, value of merchandise for the money, friendliness of sales personnel, frequency of promotional offers, offering personalized services, display of merchandise, store design, store ambience, parking facilities, customer loyalty programs. 


\section{International Journal of Current Science Research and Review}

ISSN: 2581-8341

Volume 04 Issue 06 June 2021

DOI: 10.47191/ijesrr/V4-i6-08, Impact Factor: 5.825

IJCSRR @ 2021

www.ijesrr.org

Table 14. KMO and Bartlett's Test

\begin{tabular}{|l|c|c|}
\hline Kaiser-Meyer-Olkin Measure of Sampling Adequacy. & $\mathbf{. 9 2 3}$ \\
\hline \multirow{2}{*}{ Bartlett's Test of Sphericity } & Approx. Chi-Square & 1307.277 \\
\cline { 2 - 4 } & df & 66 \\
\cline { 2 - 4 } & Sig. & .000 \\
\hline
\end{tabular}

The first table obtained after conducting the factor analysis was KMO and Bartlett's Test Table.

The first value in the table is 0.923 which shows the Kaiser-Meyer-Olkin Measure of Sampling Adequacy. The value is very close 1 which clearly signifies that the data is very well suited to conduct factor analysis. It also shows that the sample is adequate for each measure as well as the complete model.

The next test is Bartlett's test of Sphericity which gives three values, Chi-Square, Degree of freedom and Significance level. The results showed the value of Chi-Square to be 1307.277 with 66 degrees of freedom. The significance level is 0.000 which is less than 0.05 symbolizing that the sample is significant for the purpose of factor analysis. This also shows that there is significant interrelationship between the variables considered for factor analysis.

Table 15. Communalities

\begin{tabular}{|l|c|c|}
\hline & Initial & Extraction \\
\hline Convenience & 1.000 & .726 \\
\hline Quality & 1.000 & .886 \\
\hline Wide Choice & 1.000 & .849 \\
\hline Value For Money & 1.000 & .853 \\
\hline Friendliness & 1.000 & .584 \\
\hline Offers & 1.000 & .448 \\
\hline Personalized Services & 1.000 & .645 \\
\hline Visual Merchandising & 1.000 & .672 \\
\hline Design & 1.000 & .700 \\
\hline Ambience & 1.000 & .692 \\
\hline Parking & 1.000 & .536 \\
\hline Loyalty & 1.000 & .572 \\
\hline Extraction Method: Principal Component Analysis. \\
\hline
\end{tabular}

The communalities table shows the amount of variance in each variable that is accounted for. The method used here was Principle Component Analysis which gave the initial values as 1 for all the factors. This shows the variance in each factor accounted by all other factors. The extraction values indicate the proportion of each variables variance accounted by the components. All the values in this column are high. This signifies that the variables are well represented by the extracted components. 


\section{International Journal of Current Science Research and Review}

ISSN: 2581-8341

Volume 04 Issue 06 June 2021

DOI: 10.47191/ijcsrr/V4-i6-08, Impact Factor: 5.825

IJCSRR @ 2021

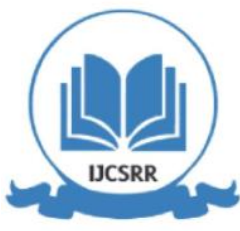

www.ijjcsrr.org

Table 16. Total Variance Explained

\begin{tabular}{|l|c|c|c|c|c|c|c|c|c|}
\hline \multirow{2}{*}{ Component } & \multicolumn{3}{|c|}{ Initial Eigenvalues } & \multicolumn{2}{c|}{$\begin{array}{c}\text { Extraction Sums of } \\
\text { Squared Loadings }\end{array}$} & \multicolumn{3}{c|}{$\begin{array}{c}\text { Rotation Sums of Squared } \\
\text { Loadings }\end{array}$} \\
\cline { 2 - 10 } & Total & $\begin{array}{c}\text { \% of } \\
\text { Variance }\end{array}$ & $\begin{array}{c}\text { Cumulat } \\
\text { ive \% }\end{array}$ & Total & $\begin{array}{c}\text { \% of } \\
\text { Varianc } \\
\text { e }\end{array}$ & $\begin{array}{c}\text { Cumula } \\
\text { tive \% }\end{array}$ & $\begin{array}{c}\text { Total } \\
\text { Varianc } \\
\text { ef }\end{array}$ & $\begin{array}{c}\text { Cumulative } \\
\%\end{array}$ \\
\hline Convenience & 6.781 & 56.510 & 56.510 & 6.781 & 56.510 & 56.510 & 4.094 & 34.120 & 34.120 \\
\hline Quality & 1.381 & 11.510 & 68.019 & 1.381 & 11.510 & 68.019 & 4.068 & 33.899 & 68.019 \\
\hline Wide Choice & .732 & 6.104 & 74.124 & & & & & & \\
\hline Value For Money & .643 & 5.357 & 79.481 & & & & & & \\
\hline Friendliness & .497 & 4.143 & 83.624 & & & & & & \\
\hline Offers & .447 & 3.725 & 87.349 & & & & & & \\
\hline Personalized Services & .430 & 3.582 & 90.931 & & & & & & \\
\hline Visual Merchandising & .315 & 2.628 & 93.559 & & & & & & \\
\hline Design & .258 & 2.148 & 95.707 & & & & & & \\
\hline Ambience & .223 & 1.855 & 97.563 & & & & & & \\
\hline Parking & .176 & 1.468 & 99.031 & & & & & & \\
\hline Loyalty & .116 & .969 & 100.000 & & & & & \\
\hline Extraction Method: Principal Component Analysis. & & & & & \\
\hline
\end{tabular}

The 'Total Variance Explained' table is divided in three major columns.

The first column is Initial Eigenvalues. This column gives the total amount of variance accounted for by each component originally. Further, it also shows the value in percentages and cumulative percentages.

The second column is called 'Extraction Sums of Squared Loadings'. This table shows the extracted components. According to the above table, we can see that there is approximately $68 \%$ of variability in the 12 factors selected. Further the data is simplified into 2 major components, which means two factors have been retained.

The third column is called 'Rotation Sums of Squared Loadings'. This column maintains the cumulative percentage shown in the second column but changes the total variance into more simplifies version and spreads it more evenly over the components. The changes suggest that it would easier to use rotated component matrix to interpret the factor reduction rather than the unrotated component matrix.

Chart 5. Scree Plot

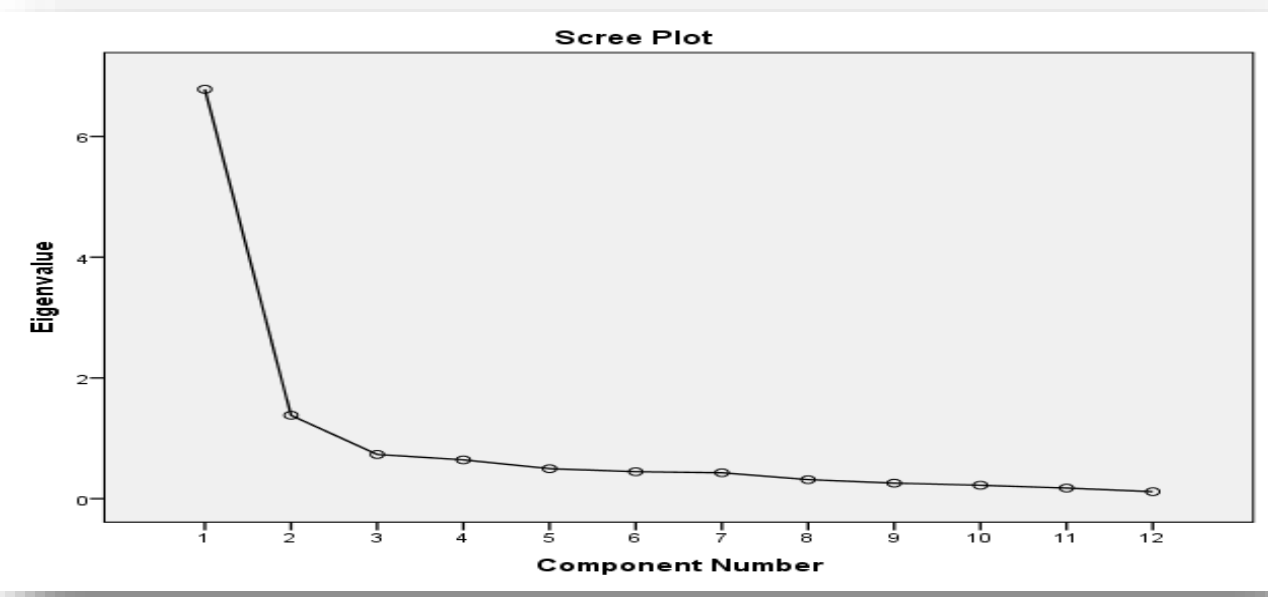




\section{International Journal of Current Science Research and Review}

ISSN: 2581-8341

Volume 04 Issue 06 June 2021

DOI: 10.47191/ijcsrr/V4-i6-08, Impact Factor: 5.825

IJCSRR @ 2021

www.ijjcsrr.org

The scree plot graphs the eigenvalues showing the total variance accounted for by the factors in the initial solution. It helps determine the optimum number of the factors that should be retained. The graph shows a steep slope till the first two components, after which the slope becomes flatter and flatter. This shows that each successive factor accounts for smaller and smaller amount of variance. Therefore, it shows that 2 factors should be retained as the slope becomes flat after the second component.

Table 17. Rotated Component Matrix

\begin{tabular}{|l|c|c|}
\hline \multirow{2}{*}{} & \multicolumn{2}{|c|}{ Component } \\
\cline { 2 - 3 } & $\begin{array}{c}\text { Attributes of the } \\
\text { Store }\end{array}$ & $\begin{array}{c}\text { Attributes of the } \\
\text { Merchandise }\end{array}$ \\
\hline Convenience & & .810 \\
\hline Quality & & .894 \\
\hline Wide Choice & & .874 \\
\hline Value For Money & .663 & .891 \\
\hline Friendliness & .790 & .497 \\
\hline Offers & .746 & \\
\hline Personalized Services & .807 & \\
\hline Visual Merchandising & .635 & \\
\hline Design & .646 & \\
\hline Ambience & & \\
\hline Parking & & \\
\hline Loyalty & & \\
\hline Extraction Method: Principal Component Analysis. & \\
\hline Rotation Method: Varimax with Kaiser Normalization. & \\
\hline a. Rotation converged in 3 iterations. & & \\
\hline
\end{tabular}

The above table is the rotated matrix table shown earlier. Here, we have removed all the values for each factor and have retained the highest values. This is because each variable is highly loaded in one factor and less loaded in other factors. After retaining the highest values, we have formed two groups. The first group consists of the factors with values in column 1 and the second group consists of factors with values in column two.

\section{Results of Factor Analysis}

The factor analysis has identified two core factors that affect the choice of the consumers while selecting a store for purchase of apparel products. These factors have been categorized as follows:

1. Attributes of the Store

2. Attributes of the Merchandise

The above factors have been discussed in detail as under: 


\section{International Journal of Current Science Research and Review}

ISSN: 2581-8341

Volume 04 Issue 06 June 2021

DOI: 10.47191/ijcsrr/V4-i6-08, Impact Factor: 5.825

IJCSRR@ 2021

www.ijcsrr.org

\section{Attributes of the Store}

This factor suggests the physical attributes of the store. This factor accounts for a total variance of $34.120 \%$ which means it accounts for $34.120 \%$ of variability in the preference of consumers according to these factors. As the variability of this factor is higher than the other factor, it shows that this factor is more important than the other factor from the point of view of the customers. This means the physical factors as a whole is an important factor for the consumers. It indicates that consumers must focus on retail store attributes as a whole to get a larger customer base.

\section{Attributes of the Merchandise}

The next factor that has been formed by grouping is the attributes of the merchandise. It accounts for a variance of $33.899 \%$ indicating that the preference of customers is affected by these factors by $33.899 \%$. The variance value is very close to the variance of the first factor which means even this group of factors is very important for the consumers. The retailers must consider this group of factors too but they are comparatively less important than the other group of factors.

A total of 2 core variables have been extracted from the list of 12 factors considered for the study. The two factors account for a cumulative variance of $68.019 \%$ which indicates the amount of variability in the preference of consumers by the grouped or core factors.

\section{RESULTS}

The study gave us the following results:

1. Out of the two store formats considered for apparel retailing in the study, it was found that the consumer of Bangalore prefer multi-brand store over an exclusive brand store.

2. Another observation made from the study was that a few demographic factors affect the frequency of visit to exclusive brand stores and multi-brand stores for apparel shopping. One of them is the gender of the consumer. It was found that females tend to be more frequent in their visit to the multi-brand stores as compared to males.

3. Along with this, the income levels of the people affect their frequency of visit to exclusive brand stores but not multi-brand stores. This means usually high income groups visit exclusive brand stores.

4. Other demographic factors like age and occupation do not have a major impact on the choice of consumers in choosing a particular retail format over the other.

5. A majority of the respondents mentioned that the amount of money spent by them in the multi-brand store is higher than the exclusive brand store in one visit.Further, ANOVA gave the results that this is affected by the income levels of the consumers. This indicates that the amount of money spent in exclusive brand stores and multi-brand stores per visit for apparel shopping by the customers in Bangalore differ with their differing income groups.

6. There were twelve factors identifies that effect the choice of the consumers in choosing an exclusive brand store or a multibrand store. All the twelve factors were found through the studies conducted earlier in the similar field by various authors. These twelve factors include convenient store location, availability of good quality merchandise, availability of wider choice / selection of merchandise, value of merchandise for the money, friendliness of sales personnel, frequency of promotional offers, offering personalized services, display of merchandise, store design, store ambience, parking facilities, customer loyalty programs.

7. The effect of the above twelve factors on the choice of customers in choosing a particular retail format was found out by conducting ANOVA. After grouping the factors, its effect was found on the first choice of the customers and it was found that the two variables have a significant relation.

8. Factor analysis was conducted to group the factors according to the impact they have on the consumer choice. The factors were grouped in the two core factors, namely, attributes of the store and attributes of the merchandise. The store attributes included friendliness of sales personnel, personalized services, display of merchandise, store design, store ambience, parking facilities and customer loyalty programs whereas the merchandise attributes included convenience, availability of quality merchandise, availability of wide choice of the merchandise, value of money for merchandise and frequency of promotional offers. It was found that the attributes of the store have more impact than attributes of the merchandise on consumer preference. 


\section{International Journal of Current Science Research and Review}

ISSN: 2581-8341

Volume 04 Issue 06 June 2021

DOI: 10.47191/ijcsrr/V4-i6-08, Impact Factor: 5.825

IJCSRR @ 2021

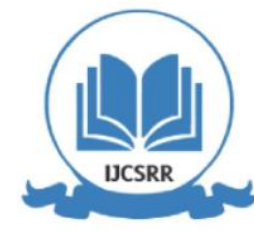

www.ijcsrr.org

\section{DISCUSSIONS}

In the field of apparel retailing, consumers visit a multi-brand outlet more often than an exclusive brand outlet, therefore it is recommended for the companies to choose the channel of multi-brand outlets for their distribution in the city of Bangalore.

However, consideration of target customers is an important aspect. If the target customers are females, the companies should opt to sell their merchandise through a multi-brand store as females visit a multi-brand store more frequently. If the target market consists of high income groups, the companies should choose to distribute their merchandise through exclusive brand stores as high income groups visit exclusive brand stores on a more frequent basis than the lower income groups.

Retailers must also consider the various factors mentioned in the study in order to get wide market coverage. The retailers must focus more on the attributes of the store than the attributes of the merchandise as the variability in preference is higher in the attributes of the store. Further, retailers must design the store in order of importance of the factors affecting consumer choice depending on if it is an exclusive brand store or a multi-brand store.

\section{CONCLUSION}

The study discusses about the importance of retail store formats. It was found that the consumers of Bangalore consider the store format while selecting a store for the purchase of apparel products. Most of the times, consumers choose a multi-brand store over an exclusive brand store and visit it more frequently than the exclusive brand stores.

There are a few demographic factors which affect the choice of the consumers. The statistical analyses prove that the factors like gender and income levels have an impact on the choice of consumers whereas other factors like age and occupation do not affect the choice of the consumers.

The study also identified twelve important factors which affect this choice of consumers. Though all the factors have some impact on the choice of the consumers, there are some factors which have high impact and there are some factors which have low impact. It was found that the seven attributes of the store have more impact than the five attributes of the merchandise on consumer preference.

In a nutshell, it is very important for any brand or any retailer to consciously decide on a retail format to operate in as it affects the choices of the customers. Further, it is very important to understand the target market well before choosing a distribution channel or setting up a store as the demographic factors of the consumers affect the preferences of the customers in terms of the retail store format, frequency of visit to the store and amount spent at the store per visit. Along with this, they must understand the factors affecting their target audience and take them into consideration to plan their marketing strategies. This would help the brand as well as the retailer to get a large customer base, which in turn will further increase the sales and overall position of the brand and the retail store.

\section{REFERENCES}

1. Behera, M. P. \& Mishra, V. (n.d.). Impact of Store Location and Layout on Consumer Purchase Behavior in Organized Retail. Anvesha-The Journal of Management, 10(1), 10-21.

2. Channar, Z. A., Panhwar, I. A., Bhatia, J., Rajput, M. \& Fatima, M. (2015). Impact of Ambiance on the Customer Purchasing Behavior. Global Management Journal for Academic \& Corporate Studies, 5 (2), 147-157.

3. Dash, M. \& L., A. (2016). A Study on the Impact of Visual Merchandising on Impulse Purchase in Apparel Retail Stores. International Journal of Marketing and Business Communication, 5(2).

4. Khare, A., Achtani, D. \&Khattar, M. (2014). Influence of price perception and shopping motives on Indian consumers' attitude towards retailer promotions in malls. Asia Pacific Journal of Marketing and Logistics, 26 (2), 272 - 295.

5. Khare, M. (2017). Single-Brand Retail Store or Multi-Brand Retail store for Information Technology Industry- The Seller Perspective. Cyber Times International Journal of Technology \& Management, 11 (1).

6. Kotni, D. P. (2016). Impact of Store Layout Design on Customer Shopping Experience: A Study of FMCG Retail Outlets in Hyderabad, India. Proceedings of Annual Australian Business and Social Science Research Conference held in Crowne Plaza Hotel, Gold Coast, Queensland, Australia, 26 - 27 September, 2016.

7. Kumar, D. M. (2015). Knowledge about Multi-Brand Outlets with Special Reference to Clothing Industry. The International Journal Of Business \& Management,3 (1), 100 - 103. 


\section{International Journal of Current Science Research and Review}

ISSN: 2581-8341

Volume 04 Issue 06 June 2021

DOI: 10.47191/ijesrr/V4-i6-08, Impact Factor: 5.825

8. Kumar, R. (2015). Store Choice: Understanding the Shoppers' Preference in Selecting an Apparel Multi-Brand Outlet. The IUP Journal of Marketing Management, 15 (1), 36-48.

9. Kureshi, S., Sood, V., \& Koshy, A. (n.d.). An In-depth Profile of the Customers of Single Brand Store in Emerging Market. South Asian Journal Of Management, 15 (2), 82 -99.

10. Thomas, S. (2013). Linking customer loyalty to customer satisfaction and store image: a structural model for retail stores. Springer, 40 (1-2), 15 - 25.DOI 10.1007/s40622-013-0007-z

11. Turhan, G. (2014). Building Store Satisfaction Centred on Customer Retention in Clothing Retailing: Store Design and Ease of Shopping. International Journal of Research in Business and Social Science, 3 (1).

12. Waerden, P. V. D., Borgers, A. \&Timmermans, H. (1998). The impact of the parking situation in shopping centres on store choice behaviour. GeoJournal, 45 (4), $309-315$.

13. Zulqarnain,H Shahzad, M. \& Zafar, A. U., (2015). Factors that Affect the Choice of Consumers in selecting Retail Store. International Journal of Multidisciplinary and Current Research, 3.

Cite this Article: Ritika Valecha, Dr. Fezeena Khadir (2021). Consumer Preference towards Choosing EBO vs. MBO with Special Reference to Apparel Retailing. International Journal of Current Science Research and Review, 4(6), 532-547 